\title{
Peculiarities of Heavy Metals Accumulation by the Plants of Meadow Phytocenosis
}

\author{
Tatyana A. Trifonova ${ }^{1}$, Ekaterina Y. Alkhutova ${ }^{2}$ \\ ${ }^{1}$ Soil Science Department, Lomonosov State University, Moscow, Russia; ${ }^{2}$ Faculty of Chemistry and Ecology, Vladimir State Uni- \\ versity, Vladimir, Russia. \\ Email: konfvladimir@mail.ru
}

Received June $12^{\text {th }}, 2012$; revised July $15^{\text {th }}, 2012$; accepted July $28^{\text {th }}, 2012$

\begin{abstract}
This work is devoted to studying of the accumulation peculiarities of heavy metals (HM) by the meadow phytocenosis plants and also plants phytomeliotating properties at various levels of soil contamination. The system "cespitose-podsol soil-meadow vegetation" has been chosen as a research object. Heavy metals as a kind of industrial waste-galvanic slurry enriched by zinc amounting $79.7 \%$ of all HM detected in the slurry-was introduced into the soil. Heavy metals content and redistribution in soil at various amount of galvanic slurry, quantitative and specific content of phytocenosis, heavy metals accumulation in the meadow vegetation crop at various contamination layers have been studied during research. Among the researched phytocenosis the groups of plants with high and low heavy metals accumulation capacity have been defined. Cirsium arvense, Capsella bursa-pastoris, Artemisia vulgarus and Rumex confertus belonged to the group accumulating several heavy metals in considerable amounts without significant phytomass loss. The majority of these plants possess developed phytomass and their ability to accumulate heavy metals in large amount allows using them as phytomeliorants for soil decontamination at the final stages of reclaiming.
\end{abstract}

Keywords: Heavy Metals; Meadow Phytocenosis Plants; Phytomeliotating Properties

\section{Introduction}

Russia like many other countries experiences vital dramatic problems of soil contamination by heavy metals. Numerous studies are devoted to the research of various aspects of this problem: HM migration in soil [1-4], soil property transformation under HM impact [5-7], HM content in soil rate setting [8-12].

From the practical point of view the problem of HM accumulation by plants and the possibility to use the plants for polluted soil decontamination ranks special interest. In case there is no necessity for urgent soil decontamination, phyto-extraction can be used as a very valuable technology possessing lots of advantages, if compared with costly physical and physical-chemical methods of reclamation. However from our point of view the questions of HM accumulation and carry-over by the plants have not been studied adequately.

This research objective was to study the accumulation peculiarities of zinc, copper, nickel, iron and cadmium by the meadow phytocenosis plants and also plants phytomeliotating properties at various levels of soil contamination.

\section{Materials and Methods}

The system "cespitose-podsol soil—meadow vegetation" has been chosen as a research object. The research was carried out in upland meadow near Vladimir city. In summer of 2006 four square plots were laid in the meadow, each plot area was $27.5 \mathrm{~m}^{2}$, the distance between the plots was about $5-8 \mathrm{~m}$. In autumn of $2006 \mathrm{HM}$ as a kind of industrial waste-galvanic slurry enriched by zinc amounting $79.7 \%$ of all $\mathrm{HM}$ detected in the slurry - was introduced into the plots soil. Nickel, copper and cadmium content in the slurry amounted $0.58,1.13$ and $0.16 \%$ correspondingly. Galvanic slurry share in the plots No. 1, No. 2, No. 3 and No. 4 amounted 0.0; 2.3; $3.5 ; 4.7 \mathrm{~kg} / \mathrm{m}^{2}$ correspondingly.

The plots were characterized by cespitose-podsol sandy-loam temporarily overdamp soil (humus $1.31 \%$, $\mathrm{pH}_{K C l} 6.22, S 6.27 \mathrm{mMole} / 100 \mathrm{~g}$ ). Soil sampling and analysis were carried out during the period of 2006-2008. Soil was sampled at the depth of $0-15,15-30,30-45$, $45-60 \mathrm{~cm}$.

Quantitative and specific content of phytocenosis was studied from 2006 till 2007, the research was carried out in mid August. Crop count was executed applying cutting method; herbage was mowed down $3-5 \mathrm{~cm}$ high. The cut plants were selected according to species and weighed air dry.

About 29 species of higher plants from 14 families 
were registered in the researched plots. With Cirsium arvense dominating, whose share comprised from $21.39 \%$ to $23.86 \%$ of total phytomass cenosis. Tragopogon pratensis $(14.60 \%-16.91 \%)$ and Dactylis glomerata $(15.60 \%$ - 17.57\%) were co-dominant. Rumex confertus and Artemisia vulgarus $(5.02 \%-7.11 \%$ and $7.97 \%-11.40 \%$ correspondingly) ranked insufficient share in the total amount of species though they had quite considerable phytomass (Figure 1).

HM gross content in galvanic slurry, soil and plants was determined by X-ray spectral fluorescent method applying "Spectroscan-MAX" device. The results of the experiment were processed using software packages "Excel" and "Statistica".

\section{Results and Discussion}

\subsection{HM Content and Redistribution in Soil at Various Amount of Galvanic Slurry}

Humus horizon pollution level of initial soil and soil deliberately contaminated with HM was assessed basing on anthropogenic contamination aggregated coefficient $\left(Z_{c}\right)$ [10]:

$$
Z_{c}=\sum_{i=1}^{n} K_{\text {total }} / K_{b g}-(n-i),
$$

with $K_{\text {total }}-\mathrm{HM}$ content in the researched soil, $K_{b g}-$ metal content in background soil, $n$-number of elements with $K_{c}>1$ (with $\mathrm{Z}_{\mathrm{c}}<16$, pollution level is considered allowable, with 16 - 32-medium, with 32 - 128-high, with $Z_{c}>128$ - very high).

Galvanic slurry introduction into the experimental plots, dosed according to the test schedule, led to the HM accumulation in soil root layer (Figure 2). Low contamination level of initial soil after introducing even minimal waste dosage has considerably increased and was characterized as "very high". By 2008 the contamination level of root layer had decreased though it had been still characterized as "very high" or "high".

In 2008 the distribution of all researched metals regarding soil type had similar characteristics not depending on galvanic slurry share. Maximum HM content attributed to the upper humus soil horizon and lower layers were characterized by elements concentration de- crease.

As mentioned above by 2008 considerable decrease of HM concentration in humus soil horizon had been observed (zinc, copper, nickel and cadmium concentration decrease comparing to 2007 comprised $62 \%$ on average for the contaminated plots); simultaneously high expected level of the considered elements in the underlying horizons $\mathrm{A}_{2}, \mathrm{~A}_{2} \mathrm{~B}$ and in the upper horizon layer $\mathrm{B}$ was not detected. Turf-spodosol soil is characterized by the scrubbing water mode so the enumerated metals, which

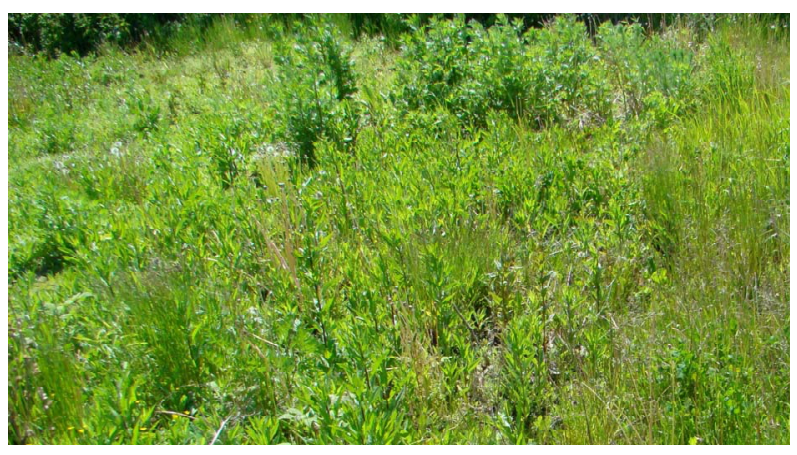

Figure 1. Test plot vegetation.

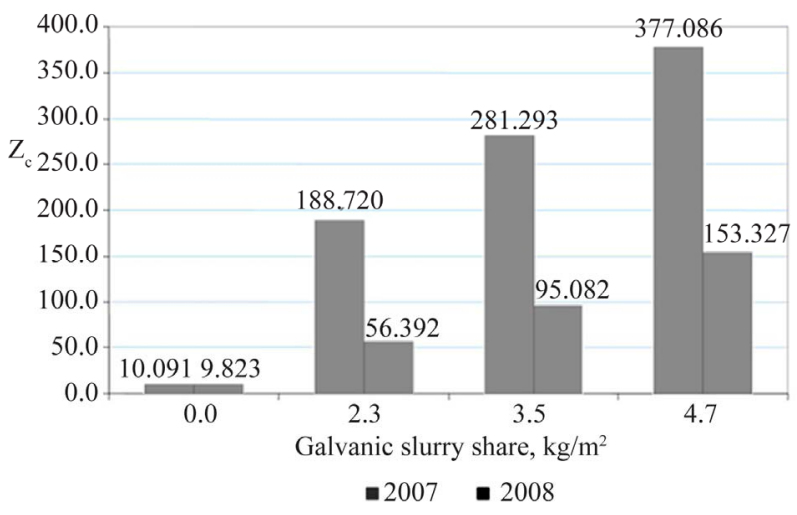

Figure 2. Anthropogenic pollution aggregated coefficient for root layer in 2007-2008.

could not get firmly fixed in the soil substance, impoverished by organics and physical clay, were washed away from the humus horizon to the $60 \mathrm{~cm}$ depth and during the flood period migrated into ground water.

\subsection{Heavy Metals Accumulation in the Meadow Vegetation Crop at Various Contamination Layers}

The tested plants accumulated HM in their tissues differently, and contamination level influenced pollutants accumulation process greatly. In order to arrange HM in a sequence, characterizing their significance for he plants, we have applied biological consumption ratio (BCR) calculated as a relation of HM content in the plants ash to HM content in soil. BCR values, calculated for HM of the test check variant $\left(\boldsymbol{Z}_{\boldsymbol{c}}=10,091\right)$, were arranged in the following sequence: $\mathrm{Zn}>\mathrm{Cu}>\mathrm{Cd}>\mathrm{Ni}>\mathrm{Fe}$ (Table 1).

Biologic accumulation sequences were changing according to the soil contamination level increase: with $\boldsymbol{Z}_{\boldsymbol{c}}$ $=188,720$ and $\boldsymbol{Z}_{\boldsymbol{c}}=281,293$ metals arranged the following sequence $\mathrm{Cu}>\mathrm{Ni}>\mathrm{Zn}>\mathrm{Cd}>\mathrm{Fe}$, but with $\boldsymbol{Z}_{\boldsymbol{c}}=$ 377,086 - the sequence was different $\mathrm{Cu}>\mathrm{Ni}>\mathrm{Zn} \approx \mathrm{Cd}$ $\approx$ Fe. Developed plants selectivity regarding copper and nickel at the plots No. 2, No. 3 and No. 4, enriched by these metals, might be explained by the fact that the plants didn't get enough amount of the mentioned above 
Table 1. Biological consumption ratios (BCR) of HM by vegetation coenosis phytomass at different levels of soil contamination.

\begin{tabular}{cccccc}
\hline \multirow{2}{*}{$\boldsymbol{Z}_{\boldsymbol{c}}$} & \multicolumn{5}{c}{ BCR (in terms of 5\% ash content) } \\
\cline { 2 - 6 } & $\mathrm{Zn}$ & $\mathrm{Cu}$ & $\mathrm{Ni}$ & $\mathrm{Fe}$ & $\mathrm{Cd}$ \\
\hline 10.091 (test) & 9.094 & 6.289 & 0.422 & 0.073 & 1.000 \\
188.72 & 0.912 & 1.467 & 1.133 & 0.126 & 0.865 \\
281.293 & 0.945 & 1.261 & 1.027 & 0.159 & 0.843 \\
377.086 & 0.780 & 1.104 & 0.817 & 0.178 & 0.783 \\
\hline
\end{tabular}

microelements from the test plot soil for a certain period of time.

For characterizing specific peculiarities of the plants to accumulate HM median-propotional method was applied, which helped to reveal the groups of plants with high, medium or low metal accumulation capacity.

Vegetation groups in terms of zinc accumulation are presented in Table 2. Zinc is a very important microelement, though is considered slightly toxic for the plants. Maximum $\mathrm{Zn}$ permissible concentration in the plants is determined in the range of $150.0-300.0 \mathrm{mg} / \mathrm{kg}$ of solids [13].

Such species as Cirsium arvense, Trifolium pratense, Tussilago farfara, Capsella bursa-pastoris, Gnaphalium ulignosum and Rumex confertus can be referred to the group with high zinc accumulation capacity. However zinc content in the plants didn't reach the lower limit of maximum permissible concentration even at the highest contamination level: maximum amount of this element was detected in No. 4 plot Capsella bursa-pastoris and comprised $139.22 \mathrm{mg} / \mathrm{kg}$ of solids.

Low accumulation capacity was typical for Conovolvulus arvensis, Vicia cracca, Tragopogon pratensis, Chenopodium rubrum, Erigeron canadensis, Mentha arvensis, Cerastium holosteoides и Pilosella onegensis. The rest meadow cenosis representatives belonged to the zinc medium accumulation capacity group.

Copper is a true bio-element, involved in various metabolic reactions of plants [14]. Nevertheless in spite of the common tolerance of the vegetable types to copper, this element is still considered to be heavily toxic. $\mathrm{Cu}$ maximum permissible concentration in plants is determined at the level of $15.0-20.0 \mathrm{mg} / \mathrm{kg}$ of dry substance [13].

Average absolute $\mathrm{Cu}$ content in plants comprised 6.04, $10.59,12.91$ and $14.16 \mathrm{mg} / \mathrm{kg}$ in the test plots No. 1, No. 2, No. 3 and No. 4 correspondingly (Table 2).

High $\mathrm{Cu}$ accumulation capacity group included Cirsium arvense, Trifolium pratense, Capsella bursa-pastoris, Artemisia vulgarus and Rumex confertus. These plants actively accumulated $\mathrm{Cu}$ both from the uncontaminated soil and from soil with high content of this element. Insignificant excess of $\mathrm{Cu}$ maximum permissible concentration in the plants was observed only at the following soil contamination levels $\boldsymbol{Z}_{\boldsymbol{c}}=281,293$ and $\boldsymbol{Z}_{\boldsymbol{c}}$ $=377,086$. Thus maximum permissible concentration excess of test plot No. 4 was detected for such plants as Cirsium arvense, Trifolium pratense, Capsella bursapastoris and Rumex confertus (copper content in these plants amounted 24.79, 20.17, 23.10 and $24.00 \mathrm{mg} / \mathrm{kg}$ of dry mass correspondingly).

Tragopogon pratensis, Linaria vulgarus, Erigeron canadensis, Cerastium holosteoides and Pilosella onegensis were featured by low copper accumulation in all the researched plots.

Cadmium is not a vital element for plants functioning it ranks among extremely toxic elements. Having equal concentrations with other HM it produces 2 - 20 times more serious negative impact on the living organisms [14].

Average ultimate cadmium content in plants, grown on the soil free from galvanic slurry, was not high and comprised $0.03 \mathrm{mg} / \mathrm{kg}$ of dry mass. As soil contami-nation grew cadmium content in dry phytomass also increased approaching its maximum value $(1303 \mathrm{mg} / \mathrm{kg})$ at $\boldsymbol{Z}_{\boldsymbol{c}}=$ 377,086 .

High rate of $\mathrm{Cd}$ accumulation was typical for such plants as Cirsium arvense, Trifolium pratense, Atriplex hastata, Tussilago farfara, Capsella bursa-pastoris, Artemisia vulgarus and Rumex confertus (Figure 3). Cadmium maximum content was registered among Cir- sium arvense in test plot No. 4 and amounted $3.09 \mathrm{mg} / \mathrm{kg}$ of dry mass.

Stellaria media, Erigeron canadensis, Gnaphalium ulignosum and Cerastium holosteoides accumulated cadmium in moderate amount.

The groups of plants with high, medium and low nickel accumulation are presented in Table 3. Despite insufficient study of nickel functions this metal is now classified as an essential microelement for the higher plants due to its physiologic importance. Ni maximum permissible concentration in plants is stated within 20.0 and $30.0 \mathrm{mg} / \mathrm{kg}$ of dry substance [13].

Polygonum persicaria, Tussilago farfara, Artemisia vulgarus and Gnaphalium ulignosum can be referred to the high nickel accumulation capacity group. These plants began to accumulate $\mathrm{Ni}$ in amounts higher than average starting with soil contamination level ranking $\boldsymbol{Z}_{c}$ $=188.720$. Cirsium arvense, Conovolvulus arvensis, $V i$ cia cracca, Epilobium rubescens, Trifolium pratense, Rumex confertus and Dactylis glomerata accumulated nickel well from soil which was not contaminated with galvanic slurry. However when soil contamination rate increased the mentioned plants $\mathrm{Ni}$ accumulating capacity fell and they were referred to medium or low accumulation capacity group. 
Table 2. Zinc and copper content in meadow phytocoenosis vegetation at various contamination levels (2007).

\begin{tabular}{|c|c|c|c|c|c|c|c|c|}
\hline \multirow{3}{*}{ Species } & \multicolumn{4}{|c|}{$\mathrm{Zn}$ content in plants, $\mathrm{mg} / \mathrm{kg}$} & \multicolumn{4}{|c|}{$\mathrm{Cu}$ content in plants, $\mathrm{mg} / \mathrm{kg}$} \\
\hline & \multicolumn{4}{|c|}{$Z_{c}$} & \multicolumn{4}{|c|}{$Z_{c}$} \\
\hline & 10.091 & 188.72 & 281.293 & 377.086 & 10.091 & 188.72 & 281.293 & 377.086 \\
\hline Atriplex hastata & 14.10 & 29.69 & 77.44 & 80.85 & 6.15 & 10.85 & 11.06 & 14.22 \\
\hline Capsella bursa-pastoris & 20.71 & 75.02 & 112.00 & 139.22 & 7.17 & 18.19 & 20.98 & 23.10 \\
\hline Cerastium holosteoides & 9.57 & 13.43 & 21.26 & 24.17 & 4.11 & 6.32 & 7.00 & 6.82 \\
\hline Chenopodium rubrum & 8.22 & 15.16 & 22.99 & 27.27 & 5.55 & 9.01 & 10.36 & 10.90 \\
\hline Cirsium arvense & 18.47 & 44.36 & 68.36 & 78.47 & 7.24 & 19.49 & 23.72 & 24.79 \\
\hline Conovolvulus arvensis & 8.11 & 14.70 & 18.42 & 20.61 & 5.19 & 7.23 & 9.88 & 10.19 \\
\hline Dactylis glomerata & 17.71 & 48.15 & 50.46 & 63.37 & 6.12 & 7.46 & 8.10 & 11.11 \\
\hline Echinochloa crusgalli & 11.22 & 26.32 & 32.64 & 44.00 & 7.05 & 10.53 & 13.06 & 14.75 \\
\hline Epilobium rubescens & 11.15 & 25.15 & 31.54 & 33.59 & 10.39 & 12.03 & 12.89 & 14.08 \\
\hline Erigeron canadensis & 10.40 & 16.69 & 15.85 & 19.23 & 4.68 & 5.83 & 6.04 & 6.16 \\
\hline Gnaphalium ulignosum & 13.46 & 33.99 & 63.66 & 106.88 & 3.94 & 10.77 & 13.88 & 15.89 \\
\hline Polygonum persicaria & 5.67 & 18.39 & 26.02 & 28.18 & 4.20 & 8.33 & 10.12 & 12.08 \\
\hline Rumex confertus & 18.03 & 40.06 & 58.97 & 71.12 & 12.84 & 18.13 & 23.95 & 24.00 \\
\hline Stellaria media & 7.03 & 19.69 & 31.61 & 39.71 & 4.36 & 8.15 & 9.68 & 10.11 \\
\hline Tragopogon pratensis & 9.25 & 13.67 & 17.84 & 22.75 & 4.44 & 5.13 & 7.10 & 8.12 \\
\hline Trifolium pratense & 8.32 & 40.05 & 82.79 & 111.52 & 7.69 & 16.91 & 18.74 & 20.17 \\
\hline Tussilago farfara & 14.05 & 37.63 & 67.10 & 75.42 & 5.93 & 11.01 & 12.15 & 13.46 \\
\hline Vicia cracca & 9.66 & 11.75 & 12.88 & 15.70 & 8.12 & 11.13 & 12.00 & 13.08 \\
\hline
\end{tabular}

\begin{tabular}{cl}
\hline Note: & \\
1 & -low heavy metals accumulation capacity plants \\
2 & -medium heavy metals accumulation capacity plants \\
3 & -high heavy metals accumulation capacity plants
\end{tabular}

Table 3. Nickel and iron content in meadow phytocoenosis plants at various pollution levels (2007).

\begin{tabular}{|c|c|c|c|c|c|c|c|c|}
\hline \multirow{3}{*}{ Species } & \multicolumn{4}{|c|}{ Ni content in plants, $\mathrm{mg} / \mathrm{kg}$} & \multicolumn{4}{|c|}{ Fe content in plants, $\mathrm{mg} / \mathrm{kg}$} \\
\hline & \multicolumn{4}{|c|}{$Z_{c}$} & \multicolumn{4}{|c|}{$Z_{c}$} \\
\hline & 10.091 & 188.72 & 281.293 & 377.086 & 10.091 & 188.72 & 281.293 & 377.086 \\
\hline Atriplex hastata & 0.08 & 4.00 & 6.11 & 7.95 & 17.92 & 30.61 & 36.76 & 40.11 \\
\hline Capsella bursa-pastoris & 0.16 & 5.01 & 6.87 & 7.06 & 28.60 & 69.29 & 83.26 & 92.14 \\
\hline Cerastium holosteoides & 0.08 & 2.05 & 3.65 & 3.07 & 12.56 & 36.98 & 52.73 & 63.09 \\
\hline Chenopodium rubrum & 0.07 & 3.15 & 6.03 & 6.17 & 43.00 & 73.00 & 85.55 & 99.92 \\
\hline Cirsium arvense & 0.65 & 4.61 & 7.12 & 11.52 & 48.40 & 73.60 & 95.98 & 104.64 \\
\hline Conovolvulus arvensis & 0.43 & 3.61 & 4.01 & 6.19 & 35.50 & 82.16 & 88.72 & 90.68 \\
\hline Dactylis glomerata & 0.38 & 1.19 & 6.00 & 6.91 & 50.71 & 60.80 & 70.88 & 83.38 \\
\hline Echinochloa crusgalli & 0.22 & 4.63 & 5.91 & 6.50 & 52.46 & 95.33 & 104.68 & 114.76 \\
\hline Epilobium rubescens & 0.63 & 3.21 & 3.86 & 4.17 & 116.61 & 68.58 & 71.11 & 77.87 \\
\hline Erigeron canadensis & 0.04 & 1.19 & 3.89 & 4.30 & 37.31 & 52.18 & 55.40 & 61.12 \\
\hline Gnaphalium ulignosum & 0.22 & 10.65 & 16.22 & 17.24 & 57.30 & 227.28 & 331.58 & 376.77 \\
\hline Polygonum persicaria & 0.28 & 6.02 & 8.64 & 10.58 & 37.37 & 112.77 & 186.92 & 229.65 \\
\hline Rumex confertus & 0.53 & 3.66 & 6.19 & 7.26 & 57.60 & 122.50 & 156.92 & 170.46 \\
\hline Stellaria media & 0.08 & 2.66 & 3.27 & 3.71 & 111.90 & 220.21 & 249.82 & 276.71 \\
\hline Tragopogon pratensis & 0.08 & 2.65 & 3.23 & 3.68 & 22.15 & 32.24 & 36.69 & 40.20 \\
\hline Trifolium pratense & 0.53 & 1.33 & 4.02 & 5.90 & 62.22 & 55.11 & 66.08 & 69.87 \\
\hline Tussilago farfara & 0.18 & 9.33 & 10.11 & 13.10 & 52.69 & 44.60 & 56.92 & 70.57 \\
\hline Vicia cracca & 0.44 & 1.79 & 2.16 & 2.58 & 54.73 & 45.55 & 48.92 & 56.30 \\
\hline
\end{tabular}

$\begin{array}{cl}\text { Note: } & 0.44 \\ 1 & \text {-low heavy metals accumulation capacity plants } \\ 2 & \text {-medium heavy metals accumulation capacity plants } \\ 3 & \text {-high heavy metals accumulation capacity plants }\end{array}$




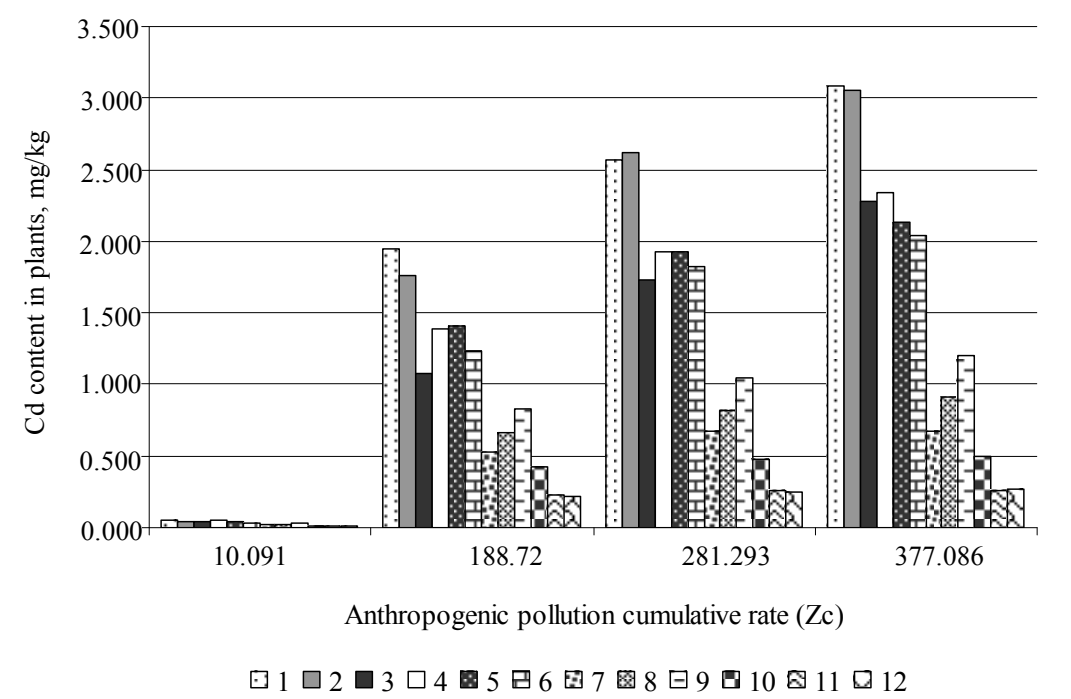

Figure 3. Cadmium content in meadow phytocenisis at various contamination levels in 2007. 1: Cirsium arvense; 2: Atriplex hastate; 3: Tussilago farfara; 4: Capsella bursa-pastoris; 5: Rumex confertus; 6: Artemisia vulgarus; 7: Vicia cracca; 8: Dactylis glomerata; 9: Tragopogon pratensis; 10: Cerastium holosteoides; 11: Erigeron Canadensis; 12: Stellaria media.

It should be noted that none of the researched plants accumulated nickel in the amount, exceeding its maximum permissible concentration in all the test plots. $\mathrm{Ni}$ maximum content was detected in plot among Artemisia vulgarus and Gnaphalium ulignosum and amounted 15.03 and $17.24 \mathrm{mg} / \mathrm{kg}$ of dry mass correspondingly.

Low zinc accumulation capacity was typical for Tragopogon pratensis, Erigeron canadensis and Cerastium holosteoides in all the test plots.

Iron is characterized by the highest concentration ratio of all metals-bioelements in plants. For gramineous plants Fe content in their phytomass is considered normal within 20.0 and $300.0 \mathrm{mg} / \mathrm{kg}$ of dry substance [15]. Fe maximum permissible concentration for gramineous plants has not been defined.

Polygonum persicaria, Stellaria media, Gnaphalium ulignosum and Rumex confertus had high iron accumulation capacity (Table 3). The mentioned above plants accumulated iron more actively with no regard to soil contamination level. Fe highest concentration (376.77 $\mathrm{mg} / \mathrm{kg}$ dry mass) was detected in Gnaphalium ulignosum phytomass and exceeded the lower limit of iron content in gramineous plants in 1.6 times.

The basic part of the plants referred to the iron medium accumulation capacity group and its averaged content in phytomass amounted 41.19, 70.15, 86.44 and $89.60 \mathrm{mg} / \mathrm{kg}$ of dry mass on plots No. 1, No. 2, No. 3 and No. 4 correspondingly.

Tragopogon pratensis, Vicia cracca, Mentha arvensis and Cerastium holosteoides belonged to the group of low iron accumulation capacity. Minimal iron content was detected in the plant-Cerastium holosteoides (12.56 $\mathrm{mg} / \mathrm{kg}$ of dry mass), grown in soil not contaminated with galvanic slurry.
It is important to state that the majority of the researched species could not bear the load of toxic heavy metals and in spite of the fact that HM ultimate content in the plants was growing due to the soil contamination level increase, plants phytomass was decreasing considerably (Figure 4).

Cocksfoot, winterweed, waterwort, timothy grass and field pansy were characterized by the most significant phytomass decrease. These plants phytomass in test plot No. 1 decreased by over $29 \%$, in No. 2 plot-over $46 \%$, in plots No. 3 and No. 4-over 85\%. Canadian thistle, goat's-beard, horse sorrel, sagebrush, caseweed and treacle mustard can be referred to the plants resistant to unfavorable growth conditions. These plants phytomass in test plot No. 1 decreased by less than $12 \%$, in plot 32-by less than $18 \%$.

Different degree of phytomass decrease in these two groups of plants can be explained by their rootage peculiarities.

As its known rootage activity has the dependence almost concurring with the relation of root mass and depth, and it monotonously decreases in the upper soil layer [16]. The basic amount of plants roots in the first group is located in the upper soil layer characterized by low moisture reserve and high contamination level. The second group of plants has pivotal rootage which is more evenly spread in soil depth, so they revealed higher stability to unfavorable environmental factors due to the possibility to absorb necessary substances from less contaminated HM of underlying soil horizon.

Considerable phytomass decrease of most researched species influence HM carry-over from the soil, which increases simultaneousely with crops growth and element concentration. Despite HM concentration increase, caused 




Figure 4. Vegetation in maximum contamination level plot.

by soil con tamination level in meadow vegetation, metals carry over from the soil decreased (Figure 5).

Experiments have revealed that HM amount, carried over from humus soil horizon with meadow phytocenosis crop, is not significant as compared with the amount washed away by the interflow. Plants share in the total elements carry-over from humus horizon comprises from $0.003 \%$ to $13.097 \%$.

Having correlated the received data, concerning rate of HM accumulation by plants and the data concerning these plants crop capacity, we have revealed the species, which can be used as phytomeliorants for contaminated soil clearance at the final stages of restoration, when HM amount in soil is not so great.

The majority of the revealed species possesses comprehensive phytomass, and its decrease compared with other representatives of meadow vegetation is minimal (with $\boldsymbol{Z}_{c}=188.720$ amounts less $18 \%$ ) (Table 4).

\section{Conclusions}

Among the researched phytocenosis the groups of plants with high and low HM accumulation capacity have been defined. The group with low HM accumulation capacity regardless pollution level includes Tragopogon pratensis, Erigeron canadensis and Cerastium holosteoides. Cirsium arvense, Capsella bursa-pastoris, Artemisia vulgarus and Rumex confertus belonged to the group accu-

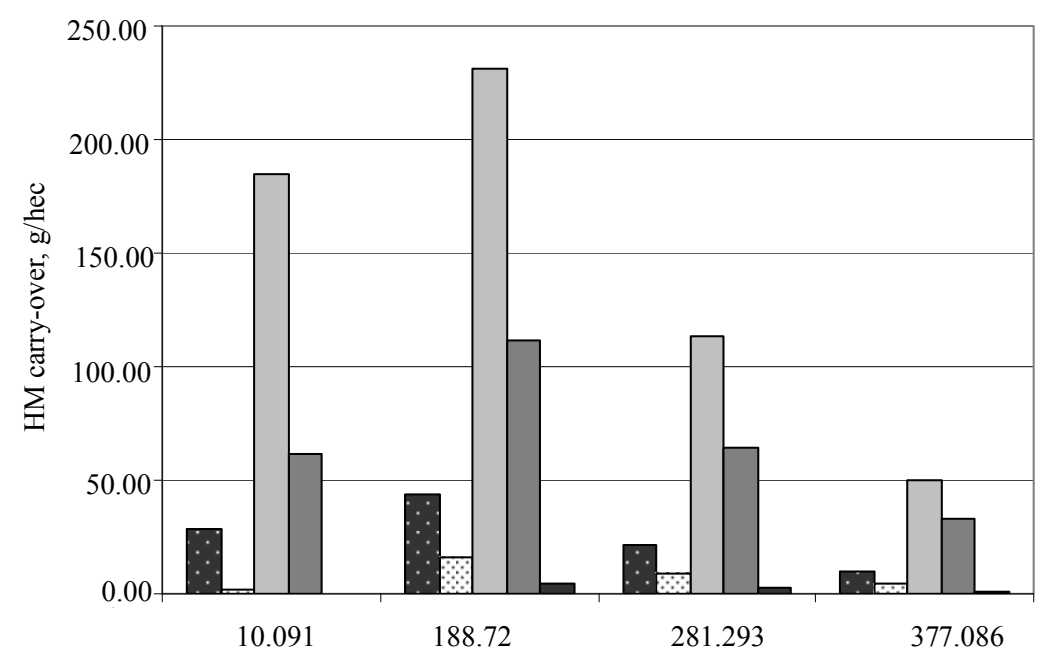

Anthropogenic pollution cumulative rate $(\mathrm{Zc})$

$\square \mathrm{Cu} \cap \mathrm{Ni} \square \mathrm{Fe} \square \mathrm{Zn} \square \mathrm{Cd}$

Figure 5. Heavy metals carry-over with meadow vegetation crop at various levels of soil contamination 2007.

Table 4. Characteristics of plants phytomeliorating properties*.

\begin{tabular}{ccccc}
\hline Species & $\begin{array}{c}\mathrm{HM}, \begin{array}{c}\text { accumulated in high } \\
\text { amount }\end{array} \\
\text { Cirsium arvense }\end{array}$ & $\begin{array}{c}\text { Phytomass variation, relative to } \\
\mathrm{Cu}, \mathrm{Zn}, \mathrm{Cd}\end{array}$ & $\begin{array}{c}\text { Plants share in the } \\
\text { association crop } \\
(2007), \%\end{array}$ & $\begin{array}{c}\text { HM carry over with } \\
\text { harvest, } \mathrm{g} / \text { hec }\end{array}$ \\
\hline $\begin{array}{c}\text { Capsella bursa-pastoris } \\
\text { Artemisia vulgarus }\end{array}$ & $\mathrm{Cu}, \mathrm{Zn}, \mathrm{Cd}$ & Decrease by $15.32 \%$ & 29.00 & 142.87 \\
Rumex confertus & $\mathrm{Ni}, \mathrm{Cd}$ & Decrease by $18.35 \%$ & 0.29 & 1.67 \\
\hline
\end{tabular}

*As phytoextraction is effective only for the low soil contamination level the table demonstrates only characteristics of plants growing in the plots with minimum galvanic slurry share in soil $(\boldsymbol{Z c}=188.720)$. 
mulating several HM in considerable amounts without significant phytomass loss. The majority of these plants possess developed phytomass and their ability to accumulate heavy metals in large amount allows using them as phytomeliorants for soil decontamination at the final stages of reclaiming.

It has been stated that for more effective HM extraction from soil it is reasonable to involve several types of plants with developed phytomass and ability to accumulate various heavy metals.

\section{REFERENCES}

[1] L. A. Shirkin, T. A. Trifonova, N. V. Selivanova and D. A. Gruzdkov, "The Heavy Metals Migration from Industrial Wastes in Soils," The International Conference on Soils Urban Industrial, Traffic and Mining Areas, Nanjing, 2007, pp. 18-27.

[2] G. V. Dobrovolsky, "Soil Degradation and Protection," MSU PH, Moscow, 2002.

[3] N. E. Kosheleva, N. S. Kasimov and O. A. Samonova, "Regressive Models of Heavy Metals Behavior in Soil of Smolensk-Moscow Upland," Soil Study, Vol. 35, No. 8, 2002, pp. 954-966.

[4] V. V. Dobrovolsky, "Humic Acids Role in Migration Formation of Heavy Metals Mass Flows," Soil Science, Vol. 1, 2004, pp. 32-40.

[5] E. V. Prokopovitch and S. Y. Kaygorodova, "Humus Soil Condition Transformation under the Impact of Emission of Sredneuralsky Copper Smelting Plant," Ecology, Vol. 5, 1999, pp. 375-378.

[6] S. I. Kolesnikov, K. Sh. Kazeev and V. F. Valkov, "Soil
Ecologic Condition and Function under the Condition of Chemical Contamination," PH Rostov University, Rostovon-Don, 2006.

[7] R. V. Galiulin and R. A. Galiulina, "Enzymatic Indication of Soil Contamination Buy Heavy Metals," Agrochemistry, Vol. 11, 2006, pp. 84-95.

[8] S. V. Lukin, Y. V. Miroshnikova and P. V. Avramenko, "Monitoring of Heavy Metals Condition in Belgorod District," Agrochemistry, Vol. 8, 2002, pp. 86-91.

[9] G. V. Motuzova and O. S. Bezuglova, "Soil Ecologic Monitoring," Academic Project, Gaudeamus, Moscow, 2007.

[10] Y. E. Saet, "Environmental Geochemistry," Nedra, Moscow, 1990

[11] I. N. Ovchinnikova and V. D. Vasilevskaya, "Soil Contamination Risk Assessment Based on Critical Load," Problems of Regional Ecology, Vol. 6, 2003, pp. 15-22.

[12] E. L. Vorobeychik and E. V. Khantemirova, "Forest Phytocoenosis Reaction for Anthropogenis Pollution: ShareEffect Dependence," Ecology, Vol. 3, 1994, pp. 31- 43.

[13] D. Saurbeck, "Welche Schwermetallgehalte in Pflanzen Dürfen Nicht Überschritten Werden, um Wachstumsbeeinträchtigungen zu Vermeiden?" Landwirtschaftliche Forschung: Kongressband, Vol. 16, 1982, pp. 59-72.

[14] N. P. Bityutsky, "Required Microelements for the Plants," PH DEAN, St.-Petersburg, 2005.

[15] A. Cottenie, A. Dhaese and R. Camerlynck, "Plant Quality Response to the Uptake of Polluting Elements," Qualitas Plantarum, Vol. 26, No. 3, 1976, pp. 293-319. doi:10.1007/BF01268209

[16] A. L. Kovalevsky, "Biogeochemistry," Science, Siberian Department, Novosibirsk, 1991. 